\title{
Refractory anemia
}

INSERM

\section{Source}

INSERM. (1999). Orphanet: an online rare disease and orphan drug data base. Refractory anemia. ORPHA:98826

Refractory cytopenias with unilineage dysplasia (RCUD) is a frequent low-risk subtype of myelodysplastic syndrome (MDS; see this term) characterized by refractory cytopenias associated with dysplasia limited to one cell lineage. 